\title{
Gendered Representation and Critical Mass: Women's Legislative Representation and Social Spending in 22 OECD Countries
}

Soon Seok Park

Sociological Perspectives 60(6):1097-1114.

\begin{abstract}
To better understand the dynamics of representation of women's interests such as public expenditure on healthcare, daycare, and education, this study examines statistical evidence for the notion of critical mass. To do so, this study uses the Comparative Welfare Data Set and the piecewise regression method to produce two linear models that best fit to the data for different ranges of the share of seats in parliament held by women. The analysis fails to find consistent support for a threshold below which women legislators have little-to-no impact upon policy outcomes. By adjudicating seven hypothetical thresholds, the analysis also shows that when there is a critical mass effect, the 10 percent level is more a consequential threshold than 15, 20, or 30 percent levels. Findings suggest that we reject the idea of a critical threshold for women's legislative representation. However, the relationship between the representation and social spending is robust with or without presumed critical mass.
\end{abstract}

Keywords: Women's Legislative Representation, Critical Mass, Welfare States, Social Spending

The causal link between descriptive and substantive representation of women's interests has been often explored but not settled. This study attempts to help clarify it by empirically testing the notion of critical mass: a proposition that the effect of descriptive representation on policy outcomes is discrete rather than continuous, with little-to-no discernible impact until the number reaches a critical threshold (Dahlerup 1988; Kanter 1977). Despite the concept's popularity among scholars and activists interested in gender equality, there is little empirical support for one particular threshold over any other. Scholars have not been able to test it statistically because pertinent data were not available until recently - there were not enough cases with 30 percent or more women's legislative representation in national legislatures. The mean percentage among OECD countries was 20.6 percent in 2002 and it is only very recently that the mean reached over 26 percent and more than 10 countries reached over 30 percent (OECD 2013). The shift produces a more appropriate distribution and provides one way to test the notion of critical mass.

As a preliminary but also important matter, this article first tackles a basic relationship between women's legislative representation and social spending. Does the representation have positive effect across policy domains? Though previous research 
suggests a positive relationship with social spending (e.g., Bolzendahl and Brooks 2007; Bolzendahl 2011; Swiss et al. 2012), a disaggregation of social spending by policy domains enables us to have a more comprehensive and nuanced understanding of the relationship (Jensen 2011). The disaggregation also makes it possible to examine whether critical masses change by the outcome of interest (Grey 2006).

This study fills an important gap in the literature on the relationship between women legislators and substantive representation of women's interests. By adjudicating hypothetical thresholds and rethinking the critical mass concept, this article demonstrates when the concept helps explain the relationship and when it does not. The findings will give the concept a more appropriate place in the literature based on empirical evidence. In addition, findings and discussion about the effects of representation on policy outcomes advance our understanding of the robustness of extant findings in the context of state retrenchment from social domains.

\section{LITERATURE REVIEW}

\section{Women's Political Representation and Social Spending}

Does women's legislative representation have a positive effect on social spending? Cross-national analyses have shown that more women legislators in parliaments are associated with more welfare state spending, accounting for per capita GDP, unemployment, percent elderly, constitutional structure, and Left and Right political representation in government (Bolzendahl and Brooks 2007; Bolzendahl 2011). Swiss et al. (2012) also find that an increase in women's legislative representation improves child health in the developing countries. Other researchers conducted crossstate level analyses with a sample of U.S. legislators and found a significant relationship between gender and support of policies toward older citizens (Giles-Sims et al. 2012) and between gender and sponsorship of social welfare bills (MacDonald and O’Brien 2011).

These studies draw on the long tradition of research on the distribution of resources and the role of the state (Allan and Scruggs, 2004; Bradley et al., 2003; Huber and Stephens 2001; Huber, Ragin, and Stephens 1993). In this approach, the state is an agent of class compromises. Prompted by structural pressures, the state uses its institutions to decide on who gets what and how. Structural pressures are economic and demographic changes in the society that encourage the state to respond. They include but are not limited to labor force participation rate, trade openness, demographic characteristics, union density, social pact, unemployment, and the Gross Domestic Product (GDP). Political institutions are intermediaries of conflicting interests. They include state structure (such as the number of veto points) and ideologies of the government (such as the share of seats held by Left parties and Christian Right parties) 
(Brady and Lee 2014).

Building on the tradition, some scholars advance the research agenda by suggesting that gender as well as other relevant factors may have varying influence on different domains of social policy (Bolzendahl 2011; Brady and Lee 2014; Jensen 2008, 2011). OECD social expenditure measures include cash benefits and services for the elderly and the disabled, sickness benefits, family cash benefits and services, labor market programs, unemployment, health, housing and other contingencies (Bolzendahl and Brooks 2007, 1517). It is hard to expect that they are all equally important "women's issues" in practice. Huber and Stephens (2001) also argued that some social services such as education and health are perceived as a public concern while some other areas such as childcare are often perceived as a concern of families. Other relevant variables may also have varying relationships by policy areas. For instance, Cohen and Centeno (2006) suggest that the impact of neoliberal globalization varies by the policy domain one considers. In addition to that, Grey (2006) suggests that we open to the possibility that different outcome variables require a different level of critical mass. Based on these theoretical expectations, I disaggregate social spending and choose three specific policy areas: healthcare, daycare, and education which are considered as “women's interests” (Bolzendahl and Brooks 2007).

In sum, it is expected that women's legislative representation will have a positive effect on public expenditure on healthcare, daycare, and education net of structural pressures and political institutions. This study follows the footsteps of earlier studies on which we contribute to a noble examination of the theory of critical mass.

\section{Testing the Theory of Critical Mass}

Although testing of the first expectation, that women's legislative representation has positive effects on social spending, would lead to a more up-to-dated and comprehensive understanding of the relationship, it would add little to previous attempts to explain the mechanisms of translation from descriptive representation to substantive representation of women's interests. To find and illustrate such mechanisms, many scholars focused on specific cases such as Belgium (Celis 2007), New Zealand (Grey 2002), Britain (Childs 2002), and Sweden (Wangerud 2000). For example, Celis (2007) argues that women MPs have diversified women's interests and realized a close correspondence between the political attention to women's interests and the way women in general perceive their interests. Thomas (1991) argues that women legislators have an impact because they give priority to women's interest issues. Though not conclusive, these scholars have attempted to fill the significant gap in our understanding of gendered representation. Another gap that needs our attention is the theory of critical mass, whose empirical evidence is lacking. 
Since Kanter (1977) introduced the idea of critical mass to social science research and Dahlerup (1988) to political research, the notion has been popular among students of women's representation as well as among activists. However, it is noteworthy that they have not agreed on a specific level of representation as a critical point. For instance, Crowley (2006) uses 15 percent as the token level and demonstrates that states with women's legislative representation over this threshold level had higher likelihood of ratifying the Equal Rights Amendment (ERA) in the United States. Giles-Sims et al. (2012) find that the American states with higher proportion of women's legislators have more favorable policies toward older citizens. They operationalize the critical mass as the number of years the state achieved the 20 percent level. Some others claim that a critical mass of women's representation emerges around 30 percent (Swiss et al. 2012). Among the claims-makers that regard 30 percent as the critical threshold, we find probably the most vocal proponent of women's political representation in the world: the United Nations (UN 2003).

Despite its popularity, the concept is being questioned by many researchers, as it suffers from the arbitrary and ad hoc methods for identifying the threshold (Beckwith and Cowell-Meyers 2007; Childs 2006; Childs and Krook 2008; Studlar and McAllister 2002). In other words, a key source of conceptual weakness is that it is not clear where the point actually is (Childs 2006). There is little evidence that tells us which point is empirically more supported than other points. The underlying concern is that there is lack of empirical basis supporting the assumption that this notion should be extended to explain the relationship between women's legislative representation and social spending. This article attempts to address this concern. Where is the critical threshold? How critical is it? Does it divide two groups of cases that have qualitatively different relationships with the outcome variable? By adjudicating hypothetical breakpoints of cross-national empirical data, this study puts the notion of critical mass to test with regard to the relationship between the representation and policy outcomes.

\section{DATA AND METHODS}

This study uses the publicly available Comparative Welfare States Data Set (Brady et al. 2014). Original data sources are the Organization for Economic Cooperation and Development (OECD) for most variables and the Visser (2013) dataset for two variables: union density and social pact. Variables are measured annually for 22 OECD countries from 1960 to 2011. Countries include Australia, Austria, Belgium, Canada, Denmark, Finland, France, Germany, Greece, Ireland, Italy, Japan, Luxembourg, Netherlands, New Zealand, Norway, Portugal, Spain, Sweden, Switzerland, United Kingdom, and United States. This provides a sample representing all four types of welfare states such as social democratic, Christian democratic, liberal, and wage earner 
welfare states. These time-series cross-sectional data also cover a longer time span than previous quantitative studies.

\section{Measurements}

This study has three outcome variables of government social spending: 1) expenditure on healthcare; 2) expenditure on daycare or home-help services under family policy; and 3) expenditure on education (all levels), all as a percentage of GDP (Gross Domestic Product). Specifically, I study the year-to-year changes in the level of spending. Women's legislative representation is the focal explanatory variable. Women's legislative representation is the share of seats in parliament held by women after the most recent election. For countries with bicameral systems, figures are for the lower chamber only.

Depending on an outcome variable, the analysis includes seven or eight structural pressure and power resources control variables. They are female labor force participation rate, trade openness, union density, social pact, unemployment, real GDP per capita (natural logged) and three demographic variables such as the percent elderly (65 or above), birth rate, and the percent youth (below 15). Female labor force participation rate is the number of female labor force as a percentage of female population between 15 and 64 years. Trade openness is measured as the sum of exports and imports as a percentage of GDP, all at current prices. It is included as an indicator of neoliberal globalization (Busemeyer 2009). Union density is net union membership as a percentage of employed wage earners. Social pact is a binary variable indicating whether a pact is negotiated between employers and employees in the country. Unemployment rate is the number of persons without employment as a percentage of the civilian labor force. GDP is a monetary value of all the goods and services produced. All GDP observations are in 2005 international dollars and natural logged.

The analysis includes two political institution variables. Left parties are a share of seats in parliament held by leftist parties. Christian Right is a share of seats in parliament held by right, Christian parties. Constitutional structure or veto points are another relevant predictor of social spending (Brady and Lee, 2014; Huber and Stephens, 2001). However, it is a time-invariant variable and, therefore, cannot be included in a fixed effects model. Following a common practice in the literature, all independent variables are lagged a year. Appendix A presents summary statistics of all variables and Appendix $B$ presents a correlation matrix.

\section{Analytic Strategy}

Data analyses in this study were conducted in two steps. First, fixed effects models (FEM) were used to estimate the effects of predictors on the public expenditure on healthcare, daycare, and education. In the welfare state literature, an alternative model 
of OLS regression with panel-corrected standard errors (PCSE) is a standard analytic strategy (e.g., Bolzendahl and Brooks 2007, Jensen 2010). This model has its strength of addressing common issues of heteroskedastic and auto-correlated errors in time-series data (Beck and Katz 1995, 1996). But, it explains the combined variations of withincountry and between-country variation. This becomes an issue because this study focuses on the theory of critical mass that should be based on variation within a given country. Therefore, considering our interests, it is most appropriate to use fixed effects models that control for the effects of unobserved stable characteristics of countries. Still, Appendix C reports OLS regression results for interested readers.

Second, to investigate whether the notion of critical mass is empirically supported, this study used a piecewise regression models. Piecewise regression produces two or more linear models that best fit to the data for different ranges of an explanatory variable. Assuming a breakpoint of “c," two linear models should be read as follows: 1) $y$ $=\mathrm{a}_{1}+\mathrm{b}_{1} x$ for $x \leq \mathrm{c}$ and 2) $y=\mathrm{a}_{2}+\mathrm{b}_{2} x$ for $x>\mathrm{c}$. This study does not constrain the models to have two segments meeting at the breakpoint. In other words, the regression function is not necessarily continuous at the breakpoint. This would allow us to see if there is an abrupt change in terms not only of slopes but also of intercepts. If the effect of critical mass were particularly strong, we would find a jump from the ending point of the linear model below the breakpoint to the beginning point of the linear model above the breakpoint. As for a baseline model, both fixed effects models and OLS with PCSE models were used because they make a very good comparison and help with interpretation of the results. They deliver substantially different results and the following sections discuss the implications of the differences. As for hypothetical points, this study includes not only the three often-claimed thresholds (15, 20, and 30) but also other points $(10,25,35$, and 40$)$ to be more inclusive of possible points of inflection.

\section{FINDINGS}

\section{Women's Legislative Representation and Social Spending}

Table 1 presents the results of fixed effects regression of healthcare, daycare, and education expenditure in 22 OECD countries from 1960 to 2011. The first column shows that female labor force participation, trade openness, the percent elderly, unemployment, and real GDP are statistically significant predictors of healthcare expenditure. The second column shows that women's legislative representation, female labor force participation, trade openness, birth rate, unemployment, GDP, and constitutional structure are statistically significant predictors of daycare expenditure. The third column shows that women's legislative representation, female labor force participation, trade openness, the percent youth, union density, social pact, unemployment, GDP, and constitutional 
structure are statistically significant predictors of daycare expenditure.

\section{(Insert Table 1 about here)}

We turn now to a comparison of effects of the key explanatory variable on three policy domains. This study confirms that women’s legislative representation has a positive effect on daycare and education expenditure, accounting for all relevant factors. A 10 percent increase of the share of seats in parliament held by women leads to, respectively, an increase of 0.12 percent (daycare) and 0.5 percent (education) in spending, all as a percentage of GDP. This may seem meager. However, this should be read in light of the base percentages of GDP. For instance, given the mean value of 0.556 percent for public expenditure on daycare and 5.299 percent for education, 0.11 percent or 0.51 percent increases are a substantial change. But, this study fails to find an independent effect of the representation on healthcare expenditure. Structural pressure and political institution variables must have explained the variance in the dependent variables despite the moderately strong correlation between two key variables ( $r=.537$ ).

As for the control variables, most of them confirm the extant findings (Bolzendahl and Brooks, 2007; Bolzendahl, 2011; Jensen, 2011). First, the female labor force participation rate is consistently found significant and has a positive effect on healthcare and daycare spending. To be more specific, a 10 percent increase of the labor force participation rate leads to, respectively, an increase of 0.40 percent (health) and .04 percent (daycare), both as a percentage of GDP. However, it is an anomaly that it has a negative effect on education spending. It should be noted that this negative effect is not robust across different models. Appendix $C$ reports the results from OLS with PCSE models and shows that it has a positive effect on education spending.

Trade openness is found negatively associated with spending in all three policy areas. It is consistent with previous research on the relationship between neoliberal globalization and social spending (Busemeyer, 2009). A relevant demographic variable for each outcome variable has a positive effect on social spending. Specifically, the percent elderly has a positive effect on health spending, birth rate on daycare, and the percent of population aged under 15 on education spending. Union density is negatively associated with education spending. But, this is another variable that changes from positive to negative when fixed effects models are used instead of OLS models (see Appendix C). Social pact has a positive effect on education spending. Unemployment has a positive effect on healthcare and education spending but a negative effect on daycare spending. GDP has a positive effect on all three policy outcomes. In contrast to Huber and Stephens (2001) and Allan and Scruggs (2004), the analysis fails to find independent effects of both Left parties and Christian Right representation on spending on any of three domains. This finding further supports a recent empirical study that rejected the idea that partisan factors drive change (Jensen 2011). 
In sum, this study with an up-to-date dataset adds support to the positive relationship between women's legislative representation and social spending. It should not be surprising that these results deviate little from extant findings- this part of the study focuses on replicating an analytic design and establishing the statistically significant relationship between two key variables. Still, the regression analysis also demonstrates merits of disaggregating the social spending indicators (Bolzendahl, 2011; Jensen 2008, 2011). For instance, the results show that the representation has an independent effect on daycare and education but not on healthcare. Findings about labor force participation and unemployment also show predictors may have different effects on different domains of social policy.

\section{Adjudicating a Critical Mass Threshold}

This study fails to find consistent support for critical mass effects. Though a critical mass effect is found for education spending, it is not supported for the relationships of women's legislative representation with healthcare or daycare expenditure. Tables 2 and 3 present slope and intercept coefficients of seven pairs of linear models that hypothetical breakpoints impose on the data. Equations for a pair should read as follows: 1) $y=\mathrm{a}_{1}+\mathrm{b}_{1} x$ for $x \leq \mathrm{c}$; and 2) $y=\mathrm{a}_{2}+\mathrm{b}_{2} x$ for $x>\mathrm{c}$, assuming a breakpoint of " $x=c$ ".

Table 2 presents piecewise regression results for education expenditure. It finds support for the notion of critical mass although the effect is small. If we consider a breakpoint that divides two linear segments with the greatest slope difference $\left(\mathrm{b}_{2}-\mathrm{b}_{1}\right), 30$ is the best supported point, followed by 25 and 10. If we regard a threshold as a point under which the independent variable has little-to-no effect effect on the outcome variable, 10 is the best supported point. Still, the effect does not seem to be large. Figure 1 illustrates the findings. The fitting lines do not get much steeper after the breakpoints. In addition to that, intercept changes show that there are more often "drops" rather than "jumps" at the breakpoints. Breakpoints 15, 20, 25 produce drops while only 35 and 40 produce jumps around the thresholds.

\section{(Insert Table 2 about here) (Insert Figure 1 about here)}

Another very important pattern shown in Table 2 is that findings from two different models are largely consistent. They both demonstrate the critical mass effects. However, findings from fixed effects models do show slightly different patterns. In comparison with the findings from OLS with PCSE models, the slope coefficients are smaller in general and the slope difference of the breakpoint 10 is substantially smaller. In

other words, between-country variation that is reflected in the OLS models does slightly increase the effect size of the women's legislative representation.

Table 3 presents the results for daycare expenditure. It shows a completely 
different pattern from the ones for education expenditure. Findings from two different models suggest that between-country variation not only inflates the overall effect of representation but also falsely creates an impression of the critical mass effect.

\section{(Insert Table 3 about here)}

Findings from OLS with PCSE models support for the notion of critical mass and the effect is greater than the one for education expenditure. If we consider a breakpoint that divides two linear segments with a greatest slope difference $\left(b_{2}-b_{1}\right)$, 35 is the best supported point followed by 40 . If we regard a threshold as a point from which the independent variable has (statistically significant) positive effect on the outcome variable, 10 is the best supported point. The figure 2 illustrates the findings. The fitting lines do get substantially steeper after the breakpoints. Though most of the intercept changes are not statistically significant, there is a jump around the breakpoint of 40 .

\section{(Insert Figure 2 about here)}

However, results from fixed effects models show that there is no critical mass effect for the relationship between women's political representation and public daycare expenditure. Slope differences show that the first slope $\left(b_{1}\right)$ is always greater than the second slope $\left(\mathrm{b}_{2}\right)$. This finding completely rejects the notion of critical mass. Two of three statistically significant intercept changes are also negative. This discrepancy among findings from each model directs our attention to the impact of between-country variation on the relationship between representation and daycare spending. It is very important to recall that the theory of critical mass is based on variation within a given country and, therefore, the results from fixed effects models carry much more weight than the ones from OLS models.

Piecewise regression results for healthcare expenditure are not reported here because the basic relationship is not statistically significant. But the findings also reject the notion of critical mass (see Appendix D). Findings from both models show that slope differences are negative. In other words, the slopes below breakpoints are steeper than the slopes above breakpoints. In addition, intercept changes are also negative. This does not mean the basic relationship between representation and healthcare spending is negative. However, it clearly shows that the effect never gets greater after any of seven breakpoints.

In sum, the piecewise regression analysis shows that the critical mass effect of women's legislative representation is not consistent across policy domains. In fact, the effect is not found in the two policy domains of daycare and healthcare. In addition to that, a comparison between results from two different models for daycare spending also illustrates that between-country variation may sometimes create a misleading piece of evidence for the critical mass effect. 


\section{DISCUSSION AND CONCLUSIONS}

This study first addressed a question: Does women's legislative representation have a positive effect on social spending across policy domains? Findings from the observations of 22 OECD countries from 1960 to 2010 confirmed that the representation has a positive effect on daycare and education spending while they failed to find an independent effect of the representation on healthcare expenditure. A large portion of observations covers the period commonly understood as neoliberal shifts since the 1980s. The findings show that the relationship is still robust in the context of state retrenchment from social domains.

Disaggregation of social spending into three policy areas not only helped confirm extant findings but also delivered interesting patterns across policy domains. Female labor force participation rate has a negative effect on education spending while it has positive effects on other domains. Unemployment has a positive effect on healthcare and education but a negative effect on daycare. Some of these effect changes might have to do with multi-collinearity among predictors. Some are not robust across different estimation models. But, the results as a whole do suggest that each policy domain may have varying relationships with some explanatory variables.

Then this study tackled its core question: Where is, if any, a critical threshold of women's legislative representation with regard to its impact on social spending? This study failed to find a consistent support for critical mass effects. The findings support the argument that we need to discard the assumption that a single number or proportion helps explain the dynamics of substantive representation (Grey 2006).

This study did find support for a critical mass effect in the relationship between women's legislative representation and education spending. But even when there is critical mass effect, the effect is not as dramatic as we usually associate with the idea of critical mass. Slope differences are very small and intercepts often drop rather than jump around the breakpoints. Another noteworthy finding is that the breakpoint of 10 best fits to the idea of qualitative different relationships below and over a threshold. Specifically, below the 10 percent level of representation, women legislators have little-to-no effect on education spending whereas they have positive and continuous effect on education spending after the threshold. It is quite surprising that the 10 percent level is one of two empirically-substantiated thresholds given that no prior research suggested this possibility. In fact, no scholars of women's political representation considered the level of representation below 15 percent as a possible threshold. ${ }^{1}$

However, Kanter (1977) did suggest the importance of critical actors rather than the sheer number in making a critical mass, and recent research reiterates the point (e.g., Chaney 2012; Childs and Krook 2008). It is particularly noteworthy that when Kanter (1977) introduced the idea of critical mass, her data were from women in corporate 
organizations. She did suggest that women below 15 percent tend to stay as a token and avoid addressing gendered issues. But, a notable difference between women in corporate settings and women in legislatures is the nature of their roles. Women in corporate settings are there to do business. They may be interested in representing women's interests but it is logically a secondary concern. However, women in a legislature are there to represent-whether they choose to “own” women's issue or not, representation is their job. Then, compared with women in corporate settings, legislators can turn into critical actors with relative ease. For instance, they have some incentive to own their gender identity and issues as suggested by a theory of "gender issue ownership" (Herrnson et al. 2003). In other words, women legislators may not even need the 15 percent level to start to make a difference.

Then, the findings from the piecewise regression models for daycare and healthcare spending take our discussion to another level. They show that slopes below breakpoints are steeper than the slopes after breakpoints, and reject the theory of critical mass. Why would this be the case? Here are a few speculations. First, it could be an effect of backlash. As Grey (2006) noted in the case study of New Zealand, as the number of women legislators grows hostility towards feminism may also grow. Ironically, it is possible that an opposition to feminist policy agenda grows as the proportion of women legislators increases. Second, it could be a matter of salience. When the group of legislators gets balanced in terms of sex ratio, the gender may become less of concern or less noteworthy. In line with that, some scholars point to the problem of heterogeneity among women that is detrimental to a coordinated advocacy (Childs and Krook 2009; Erzeel 2015). Still, these remain speculative. But, it is relatively clearer that the theory of critical mass largely fails to help explain the relationship between women legislators and social spending.

The most important drawback of the theory of critical mass may be that it was presented as if it were a simple formula for a complex process of turning descriptive representation into substantive representation. Scholars already have demonstrated the importance of core executives (Annesley and Gains 2010), the electoral system (Tremblay 2006), institutional rules (Mendelberg et al. 2014), parliamentary and civil society contexts (Beckwith and Cowell-Meyers 2007), and political parties (Studlar and McAllister 2002) for representing women's interests. Complementary to their findings, this study presented statistical evidence that there is, if any, no single point at which critical mass is achieved.

It has to be acknowledged that a quantitative cross-national study may not be the only way to examine dynamics of critical mass. Some scholars also defined the notion in a different way. For example, Studlar and McAllister (2002) operationalized it as "an acceleration effect” on the election of more women. This study may apply to those cases. 
This study also fails to include a more global sample due to the problem of data availability. A study with an expanded sample of all democracies will be a worthwhile future research. Meanwhile, this statistical analysis of up-to-date cross-national data from 22 developed countries does suggest that the notion of critical mass is not consistently supported by the empirical data. It may have been the case that the notion has been overextended to the research on representation.

Political implications of the findings are empowering rather than discouraging. We need to recall the basic positive relationship between the level of representation and the level of spending. Previous claims on critical mass inadvertently delivered disempowering messages to the policymakers and their allies. It was as if women legislators would not make a real difference unless they have more of them. But this study finds that representatives do make differences with or without presumed critical mass of 15, 20 or 30 percent seats in parliaments. This study does not oppose or delegitimize the validity of the claim that women deserve or need more political representation. But, it does oppose the proposition that women legislators cannot make a difference on social spending until they reach a certain proportion of representation.

\footnotetext{
${ }^{1}$ Giles-Sims et al. (2012) notes that Paxton, Hughes, and Green (2006) considered 10\% as a "bare" threshold although they primarily considered $30 \%$ a critical mass.
} 


\section{REFERENCES}

Allan, James P., and Lyle Scruggs. 2004. "Political Partisanship and Welfare State Reform in Advanced Industrial Societies.” American Journal of Political Science 48(3):496-512.

Annesley, Claire, and Francesca Gains. 2010. “The Core Executive: Gender, Power and Change.” Political Studies 58: 909-29.

Beck, Nathaniel and Jonathan N. Katz. 1995. "What To Do (and Not To Do) with TimeSeries Cross section Data.” American Political Science Review 89 (3): 634-647

Beck, Nathaniel and Jonathan N. Katz. 1996. "Nuisance vs. Substance: Specifying and Estimating Time-Series-Cross-Section Models.” Political Analysis 6: 1-36.

Beckwith, Karen, and Kimberly Cowell-Meyers. 2007. "Sheer Numbers: Critical Representation Thresholds and Women’s Political Representation.” Perspectives on Politics 5(3): 553-565.

Bolzendahl, Catherine and Clem Brooks. 2007. "Women's Political Representation and Welfare State Spending in 12 Capitalist Democracies.” Social Forces 85 (4): 15091534.

Bolzendahl, Catherine. 2011. "Beyond the Big Picture: Gender Influences on Disaggregated and Domain-Specific Measures of Social Spending, 1980-1999.” Politics \& Gender 7 (1): 35-70.

Bonoli, Giuliano and Frank Reber. 2010. "The Political Economy of Childcare in OECD Countries: Explaining Cross-National Variation in Spending and Coverage Rates.” European Journal of Political Research 49 (1): 97-118.

Bradley, David, Evelyne Huber, Stephanie Moller, Francois Nielsen, and John D. Stephens. 2003. "Distribution and Redistribution in Postindustrial Democracies." World Politics 55(2):193-228.

Brady, David, Evelyne Huber, and John D. Stephens. 2014. Comparative Welfare States Data Set. University of North Carolina and WZB Berlin Social Science Center.

Brady, David, and Hang Young Lee. 2014. "The Rise and Fall of Government Spending in Affluent Democracies, 1971-2008.” Journal of European Social Policy 24(1): 5679.

Busemeyer, Marius R. 2009. "From Myth to Reality: Globalization and Public Spending in OECD Countries Revisited.” European Journal of Political Research 48: 455482.

Celis, Karen. 2007. “Substantive Representation of Women: The Representation of Women's Interests and the Impact of Descriptive Representation in the Belgian Parliament (1900-1979).” Journal of Women, Politics \& Policy 28 (2): 85-114.

Chaney, Paul. 2012. "Critical Actors vs. Critical Mass: The Substantive Representation of Women in the Scottish Parliament.” British Journal of Politics and International 
Relations 14(3): 441-57.

Childs, Sarah. 2002. “Hitting the Target: Are Labour Women MPs 'Acting for' Women?” Parliamentary Affairs 55 (1): 143-153.

Childs, Sarah. 2006. "The Complicated Relationship between Sex, Gender and the Substantive Representation of Women.” European Journal of Women's Studies 13 (1): 7-21.

Childs, Sarah and Mona Lena Krook. 2008. “Critical Mass Theory and Women’s Political Representation.” Political Studies 56 (3): 725-736.

Childs, Sarah, and Mona Lee Krook. 2009. “Analyzing Women’s Substantive Representation: From Critical Mass to Critical Actors.” Government and Opposition 44(2):125-45.

Cohen, Joseph N. and Miguel A. Centeno. 2006. "Neoliberalism and Patterns of Economic Performance, 1980-2000.” Annals of the American Academy of Political and Social Science 606: 32-67.

Crowley, Jocelyn E. 2006. "Moving Beyond Tokenism: Ratification of the Equal Rights Amendment and the Election of Women to State Legislatures.” Social Science Quarterly 87 (3): 519-539.

Dahlerup, Drude. 1988. "From a Small to a Large Minority: Women in Scandinavian Politics.” Scandinavian Political Studies 11 (4): 275-297.

Dahlerup, Drude. 2006. “The Story of the Theory of Critical Mass.” Politics \& Gender 2(4):511-522.

Erzeel, Silvia. 2015. “Explaining Legislators’ Actions on Behalf of Women in the Parliamentary Party Group: The Role of Attitudes, Resources, and Opportunities.” Journal of Women, Politics \& Policy 36:440-463.

Giles-Sims, Jean, Joanne C. Green, and Charles Lockhart. 2012. “Do Women Legislators Have a Positive Effect on the Supportiveness of States Toward Older Citizens?” Journal of Women, Politics \& Policy 33 (1): 38-64.

Grey, Sandra. 2002. "Does Size Matter? Critical Mass and New Zealand's Women MPs." Parliamentary Affairs 55 (1): 19-29.

Grey, Sandra. 2006. "Numbers and Beyond: The Relevance of Critical Mass in Gender Research.” Politics \& Gender 2(4):492-502.

Herrnson, Paul. S., J. Celeste Lay, and Atiya Kai Stokes. 2003. “Women Running 'As Women’: Candidate Gender, Campaign Issues, and Voter-Targeting Strategies.” Journal of Politics 65 (1): 244-55.

Huber, Evelyne, Charles Ragin, and John D. Stephens. 1993. "Social Democracy, Christian Democracy, Constitutional Structure, and the Welfare State.” American Journal of Sociology 99(3): 711-749.

Huber, Evelyne, and John D. Stephens. 2001. Development and Crisis of the Welfare 
State. Chicago, IL: The University of Chicago Press.

Jensen, Carsten. 2008. "World of Welfare Services and Transfers." Journal of European Social Policy 18: 151-62.

Jensen, Carsten. 2010. Issue Compensation and Right-wing Government Social Spending.” European Journal of Political Research 49(2):282-299.

Jensen, Carsten. 2011. "Determinants of Welfare Service Provision After the Golden Age.” International Journal of Social Welfare 20(2):125-134.

Kanter, Rosabeth M. 1977. "Some Effects of Proportions on Group Life: Skewed Sex Ratios and Responses to Token Women.” American Journal of Sociology 82 (5): 965-990.

MacDonald, Jason A. and Erin O'Brien E. 2011. “Quasi-Experimental Design, Constituency, and Advancing Women's Interests: Reexamining the Influence of Gender on Substantive Representation.” Political Research Quarterly 64 (2): 472486.

Mendelberg, Tali, Christopher F. Karpowitz and Nicholas Goedert. 2014. "Does Descriptive Representation Facilitate Women's Distinctive Voice? How Gender Composition and Decision Rules Affect Deliberation.” American Journal of Political Science 58 (2): 291-306.

OECD iLibrary. 2013. “Government at a Glance 2013.” Retrieved December 18th, 2014. (http://www.oecd-ilibrary.org/sites/gov_glance-2013-en/06/04/index.html).

Paxton, Pamela, Melanie M. Hughes, and Jennifer L. Green. 2006. "The International Women's Movement and Women's Political Representation, 1893-2003.” American Sociological Review 71 (6):898-920.

Studlar, Donley, and Ian McAllister. 2002. "Does a Critical Mass Exist? A Comparative Analysis of Women's Legislative Representation since 1950.” European Journal of Political Research 41(2): 233-53.

Swiss, Liam, Kathleen M. Fallon and Giovani Burgos. 2012. "Does Critical Mass Matter? Women's Political Representation and Child Health in Developing Countries." Social Forces 91 (2): 531-557.

Thomas, Sue. 1991. “The Impact of Women on State Legislative Policies.” Journal of Politics 53 (4): 958-976.

Tremblay, Manon. 2006. "The Substantive Representation of Women and PR: Some Reflections on the Role of Surrogate Representation and Critical Mass.” Politics \& Gender 2(4):502-511.

United Nations Equal Opportunity Commission. 2003. "United Nations Targets for Proportion of Women in Leadership and Decision-Making Positions.” Information Paper.

Visser, Jelle. 2013. Data Base on Institutional Characteristics of Trade Unions, Wage 
Setting, State Intervention and Social Pacts, 1960-2011 (ICTWSS). Amsterdam Institute for Advanced Labour Studies. Version. 4.

Wangnerud, Lena. 2000. "Testing the Politics of Presence: Women's Representation in the Swedish Riksdag.” Scandinavian Political Studies 23 (1): 67-91. 
Table 1. Regression of Healthcare, Daycare, and Education Expenditure in 22 OECD Countries, 1960-2011 (Fixed Effects Models)

\begin{tabular}{llll}
\hline & Healthcare (992) & Daycare (582) & Education (633) \\
\hline Representation & $.002(.006)$ & $.012^{* *}(.002)$ & $.050^{* *}(.006)$ \\
Female labor force & $.040^{* *}(.005)$ & $.004^{*}(.002)$ & $-.038^{* *}(.007)$ \\
Trade openness & $-.006^{* *}(.002)$ & $-.002^{* *}(.001)$ & $-.006^{*}(.003)$ \\
Elderly & $.103^{* *}(.023)$ & & \\
Birth rate & & $.180^{*}(.081)$ & \\
Youth & & $-.004(.006)$ & $.080^{* *}(.021)$ \\
Union density & $.002(.003)$ & $-.003(.001)$ & $-.019^{* *}(.004)$ \\
Social pact & $.100(.073)$ & $-.027(.017)$ & $.148^{*}(.066)$ \\
Unemployment & $.036^{* *}(.011)$ & $-.012^{* *}(.003)$ & $.076^{* *}(.011)$ \\
GDP (log) & $1.634^{* *}(.163)$ & $.248^{* *}(.066)$ & $1.000^{* *}(.223)$ \\
Left parties & $-.000(.001)$ & $.000(.000)$ & $.001(.001)$ \\
Christian Right & $-.006(.003)$ & $.001(.001)$ & $.015(.008)$ \\
Constant & $-14.341^{* *}(1.344)$ & $-2.291^{* *}(.683)$ & $-4.367(2.436)$ \\
F statistic & $193.2^{* *}$ & $58.07^{* *}$ & $21.81^{* *}$ \\
\hline
\end{tabular}

Note: Unstandardized regression coefficients are shown with standard errors in parentheses. All variables are lagged 1 year. ${ }^{*} \mathrm{p}<.05 ;{ }^{* *} \mathrm{p}<.01$ 
Table 2. Piecewise Regression of Education Expenditure on Female Legislative Representation ( $\mathrm{N}=633)$

\begin{tabular}{|c|c|c|c|c|c|c|c|c|}
\hline Models & Coefficients & 10 & 15 & 20 & 25 & 30 & 35 & 40 \\
\hline & Slope 1 & $\begin{array}{l}.001 \\
(.020)\end{array}$ & $\begin{array}{l}.042 * * \\
(.009)\end{array}$ & $\begin{array}{l}.053^{* *} \\
(.007)\end{array}$ & $\begin{array}{l}.043 * * \\
(.005)\end{array}$ & $\begin{array}{l}.039 * * \\
(.005)\end{array}$ & $\begin{array}{l}.043 * * \\
(.004)\end{array}$ & $\begin{array}{l}.053 * * \\
(.004)\end{array}$ \\
\hline & Intercept 1 & $\begin{array}{l}4.664^{* *} \\
(.108)\end{array}$ & $\begin{array}{l}4.454^{* *} \\
(.083)\end{array}$ & $\begin{array}{l}4.390 * * \\
(.081)\end{array}$ & $\begin{array}{l}4.457 * * \\
(.070)\end{array}$ & $\begin{array}{l}4.486^{* *} \\
(.071)\end{array}$ & $\begin{array}{l}4.454^{* *} \\
(.072)\end{array}$ & $\begin{array}{l}4.353^{* *} \\
(.074)\end{array}$ \\
\hline & Slope 2 & $\begin{array}{l}.059 * * \\
(.004)\end{array}$ & $\begin{array}{l}.067 * * \\
(.006)\end{array}$ & $\begin{array}{l}.089 * * \\
(.007)\end{array}$ & $\begin{array}{l}.108^{* *} \\
(.011)\end{array}$ & $\begin{array}{l}.110^{* *} \\
(.016)\end{array}$ & $\begin{array}{l}.078 * * \\
(.017)\end{array}$ & $\begin{array}{l}-.013 \\
(.018)\end{array}$ \\
\hline & $\begin{array}{l}\text { Intercept } \\
\text { change }\end{array}$ & $\begin{array}{l}.154 \\
(.158)\end{array}$ & $\begin{array}{l}-.117 \\
(.141)\end{array}$ & $\begin{array}{l}-.480^{* *} \\
(.118)\end{array}$ & $\begin{array}{l}-.330^{*} \\
(.145)\end{array}$ & $\begin{array}{l}.055 \\
(.181)\end{array}$ & $\begin{array}{l}.472 * * \\
(.160)\end{array}$ & $\begin{array}{l}.559 * * \\
(.142)\end{array}$ \\
\hline & $\begin{array}{l}\text { Slope } \\
\text { difference }\end{array}$ & $\begin{array}{l}.060 * * \\
(.018)\end{array}$ & $\begin{array}{l}.025 * * \\
(.007)\end{array}$ & $\begin{array}{l}.037 * * \\
(.008)\end{array}$ & $\begin{array}{l}.064^{* *} \\
(.012)\end{array}$ & $\begin{array}{l}.071^{* *} \\
(.016)\end{array}$ & $\begin{array}{l}.050 * \\
(.021)\end{array}$ & $\begin{array}{l}-.066^{* *} \\
(.019)\end{array}$ \\
\hline & R square & .303 & .301 & .312 & .312 & .311 & .311 & .299 \\
\hline & Slope 1 & $\begin{array}{l}-.001 \\
(.018)\end{array}$ & $\begin{array}{l}.027 * \\
(.011)\end{array}$ & $\begin{array}{l}.029 * * \\
(.008)\end{array}$ & $\begin{array}{l}.021^{* *} \\
(.006)\end{array}$ & $\begin{array}{l}.021^{* *} \\
(.005)\end{array}$ & $\begin{array}{l}.024 * * \\
(.004)\end{array}$ & $\begin{array}{l}.032 * * \\
(.004)\end{array}$ \\
\hline & Intercept 1 & $\begin{array}{l}4.921^{* *} \\
(.120)\end{array}$ & $\begin{array}{l}4.776^{* *} \\
(.096)\end{array}$ & $\begin{array}{l}4.753^{* *} \\
(.082)\end{array}$ & $\begin{array}{l}4.813^{* *} \\
(.074)\end{array}$ & $\begin{array}{l}4.808^{* *} \\
(.070)\end{array}$ & $\begin{array}{l}4.775^{* *} \\
(.066)\end{array}$ & $\begin{array}{l}4.701^{* *} \\
(.064)\end{array}$ \\
\hline & Slope 2 & $\begin{array}{l}.039 * * \\
(.005)\end{array}$ & $\begin{array}{l}.048 * * \\
(.006)\end{array}$ & $\begin{array}{l}.068 * * \\
(.008)\end{array}$ & $\begin{array}{l}.080 * * \\
(.012)\end{array}$ & $\begin{array}{l}.091 * * \\
(.019)\end{array}$ & $\begin{array}{l}.066^{*} \\
(.032)\end{array}$ & $\begin{array}{l}-.054 \\
(.069)\end{array}$ \\
\hline & $\begin{array}{l}\text { Intercept } \\
\text { change }\end{array}$ & $\begin{array}{l}.004 \\
(.109)\end{array}$ & $\begin{array}{l}-.235^{*} \\
(.117)\end{array}$ & $\begin{array}{l}-.424^{* *} \\
(.125)\end{array}$ & $\begin{array}{l}-.211 \\
(.140)\end{array}$ & $\begin{array}{l}.007 \\
(.151)\end{array}$ & $\begin{array}{l}.373^{*} \\
(.143)\end{array}$ & $\begin{array}{l}.692^{*} \\
(.318)\end{array}$ \\
\hline & $\begin{array}{l}\text { Slope } \\
\text { difference }\end{array}$ & $\begin{array}{l}.039 * \\
(.018)\end{array}$ & $\begin{array}{l}.021 \\
(.012)\end{array}$ & $\begin{array}{l}.039 * * \\
(.010)\end{array}$ & $\begin{array}{l}.060 * * \\
(.013)\end{array}$ & $\begin{array}{l}.070 * * \\
(.020)\end{array}$ & $\begin{array}{l}.054^{*} \\
(.026)\end{array}$ & $\begin{array}{l}-.086 \\
(.069)\end{array}$ \\
\hline & F statistic & $32.04 * *$ & $33.71^{* *}$ & $39.39 * *$ & $37.92 * *$ & $37.22 * *$ & $36.43 * *$ & $31.45^{* *}$ \\
\hline
\end{tabular}

Note: Unstandardized regression coefficients are shown with standard errors in parentheses. ${ }^{*} \mathrm{p}$ $<.05 ; * * \mathrm{p}<.01$ 
Table 3. Piecewise Regression of Daycare Expenditure on Female Legislative Representation ( $\mathbf{N}=\mathbf{5 8 1})$

\begin{tabular}{|c|c|c|c|c|c|c|c|c|}
\hline Models & Coefficients & 10 & 15 & 20 & 25 & 30 & 35 & 40 \\
\hline & Slope 1 & $\begin{array}{l}.006 \\
(.007)\end{array}$ & $\begin{array}{l}.018 * * \\
(.005)\end{array}$ & $\begin{array}{l}.022 * * \\
(.005)\end{array}$ & $\begin{array}{l}.020 * * \\
(.004)\end{array}$ & $\begin{array}{l}.024 * * \\
(.003)\end{array}$ & $\begin{array}{l}.028 * * \\
(.002)\end{array}$ & $\begin{array}{l}.030 * * \\
(.001)\end{array}$ \\
\hline & Intercept 1 & $\begin{array}{l}.135^{* *} \\
(.049)\end{array}$ & $\begin{array}{l}.078 \\
(.049)\end{array}$ & $\begin{array}{l}.047 \\
(.049)\end{array}$ & $\begin{array}{l}.063 \\
(.047)\end{array}$ & $\begin{array}{l}.024 \\
(.045)\end{array}$ & $\begin{array}{l}-.025 \\
(.036)\end{array}$ & $\begin{array}{l}-.049 * \\
(.023)\end{array}$ \\
\hline & Slope 2 & $\begin{array}{l}.035^{* *} \\
(.002)\end{array}$ & $\begin{array}{l}.042^{* *} \\
(.002)\end{array}$ & $\begin{array}{l}.048^{* *} \\
(.003)\end{array}$ & $\begin{array}{l}.048^{* *} \\
(.006)\end{array}$ & $\begin{array}{l}.053^{* *} \\
(.008)\end{array}$ & $\begin{array}{l}.078 * * \\
(.006)\end{array}$ & $\begin{array}{l}.063^{* *} \\
(.012)\end{array}$ \\
\hline & $\begin{array}{l}\text { Intercept } \\
\text { change }\end{array}$ & $\begin{array}{l}-.010 \\
(.052)\end{array}$ & $\begin{array}{l}-.104 \\
(.068)\end{array}$ & $\begin{array}{l}-.123 \\
(.089)\end{array}$ & $\begin{array}{l}.046 \\
(.089)\end{array}$ & $\begin{array}{l}.070 \\
(.081)\end{array}$ & $\begin{array}{l}-.002 \\
(.062)\end{array}$ & $\begin{array}{l}.217^{* *} \\
(.052)\end{array}$ \\
\hline & $\begin{array}{l}\text { Slope } \\
\text { difference }\end{array}$ & $\begin{array}{l}.030 * * \\
(.008)\end{array}$ & $\begin{array}{l}.024 * * \\
(.007)\end{array}$ & $\begin{array}{l}.026^{* *} \\
(.006)\end{array}$ & $\begin{array}{l}.028 * * \\
(.007)\end{array}$ & $\begin{array}{l}.030 * * \\
(.009)\end{array}$ & $\begin{array}{l}.053 * * \\
(.011)\end{array}$ & $\begin{array}{l}.033^{* *} \\
(.012)\end{array}$ \\
\hline & $\mathrm{R}$ square & .498 & .509 & .515 & .511 & .507 & .510 & .499 \\
\hline & Slope 1 & $\begin{array}{l}.028 * * \\
(.007)\end{array}$ & $\begin{array}{l}.034^{* *} \\
(.004)\end{array}$ & $\begin{array}{l}.032 * * \\
(.003)\end{array}$ & $\begin{array}{l}.027 * * \\
(.002)\end{array}$ & $\begin{array}{l}.024^{* *} \\
(.001)\end{array}$ & $\begin{array}{l}.024^{* *} \\
(.001)\end{array}$ & $\begin{array}{l}.024^{* *} \\
(.001)\end{array}$ \\
\hline & Intercept 1 & $\begin{array}{l}.030 \\
(.051)\end{array}$ & $\begin{array}{l}.03 \\
(.035)\end{array}$ & $\begin{array}{l}.012 \\
(.030)\end{array}$ & $\begin{array}{l}.062 * \\
(.026)\end{array}$ & $\begin{array}{l}.085^{* *} \\
(.024)\end{array}$ & $\begin{array}{l}.093 * * \\
(.022)\end{array}$ & $\begin{array}{l}.093^{* *} \\
(.021)\end{array}$ \\
\hline & Slope 2 & $\begin{array}{l}.017 * * \\
(.001)\end{array}$ & $\begin{array}{l}.018 * * \\
(.002)\end{array}$ & $\begin{array}{l}.018^{* *} \\
(.002)\end{array}$ & $\begin{array}{l}.017^{* *} \\
(.003)\end{array}$ & $\begin{array}{l}.006 \\
(.004)\end{array}$ & $\begin{array}{l}-.014 \\
(.008)\end{array}$ & $\begin{array}{l}.022 \\
(.017)\end{array}$ \\
\hline & $\begin{array}{l}\text { Intercept } \\
\text { change }\end{array}$ & $\begin{array}{l}.104^{* *} \\
(.030)\end{array}$ & $\begin{array}{l}-.012 \\
(.031)\end{array}$ & $\begin{array}{l}-.075^{*} \\
(.032)\end{array}$ & $\begin{array}{l}-.034 \\
(.035)\end{array}$ & $\begin{array}{l}.037 \\
(.035)\end{array}$ & $\begin{array}{l}.046 \\
(.038)\end{array}$ & $\begin{array}{l}-.373^{* *} \\
(.074)\end{array}$ \\
\hline & $\begin{array}{l}\text { Slope } \\
\text { difference }\end{array}$ & $\begin{array}{l}-.011 \\
(.007)\end{array}$ & $\begin{array}{l}-.016^{* *} \\
(.004)\end{array}$ & $\begin{array}{l}-.014 * * \\
(.003)\end{array}$ & $\begin{array}{l}-.010^{* *} \\
(.003)\end{array}$ & $\begin{array}{l}-.018^{* *} \\
(.004)\end{array}$ & $\begin{array}{l}-.024^{* *} \\
(.006)\end{array}$ & $\begin{array}{l}-.001 \\
(.017)\end{array}$ \\
\hline & F statistic & $160.2^{* *}$ & $153.0 * *$ & $155.2^{* *}$ & $149.4^{* *}$ & $152.5^{* * *}$ & $153.3^{* *}$ & $171.2^{* *}$ \\
\hline
\end{tabular}

Note: Unstandardized regression coefficients are shown with standard errors in parentheses. ${ }^{*} \mathrm{p}$ $<.05 ;{ }^{* *} \mathrm{p}<.01$ 
Figure 1. Scatter Plots of Female Legislative Representation and Education Expenditure
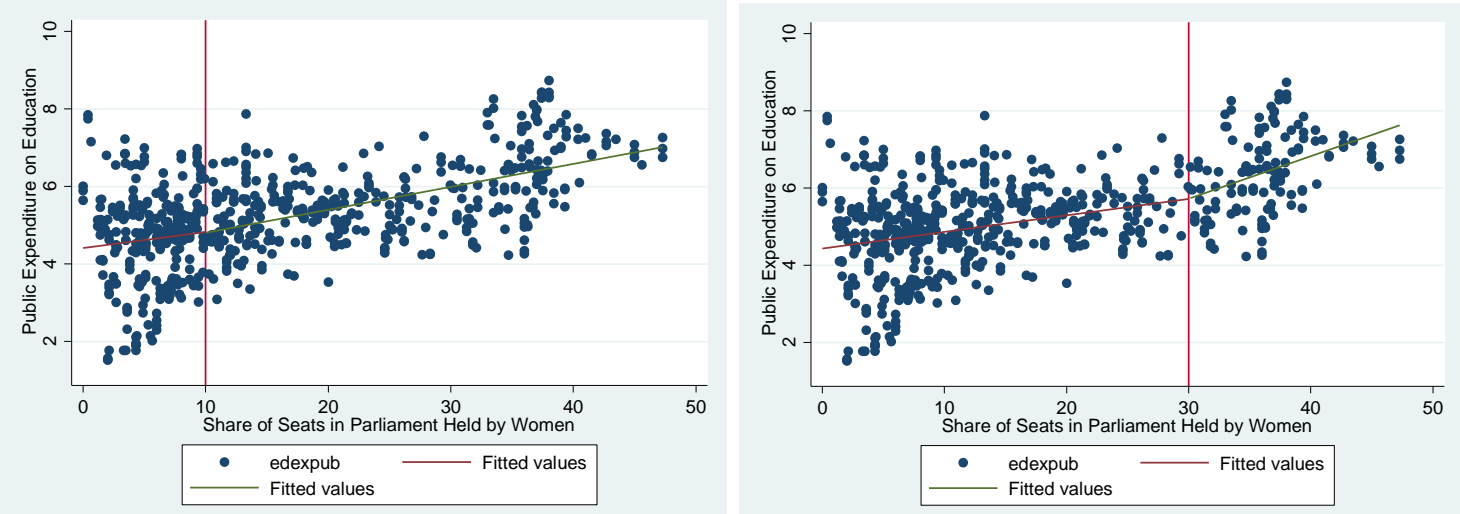

Note: Both variables are shown in percentage. Fitting lines presented above are produced by the breakpoint of 10 (left) and by the one of 30 (right) in the OLS regression models. 
Figure 2. Scatter Plots of Female Legislative Representation and Daycare Expenditure
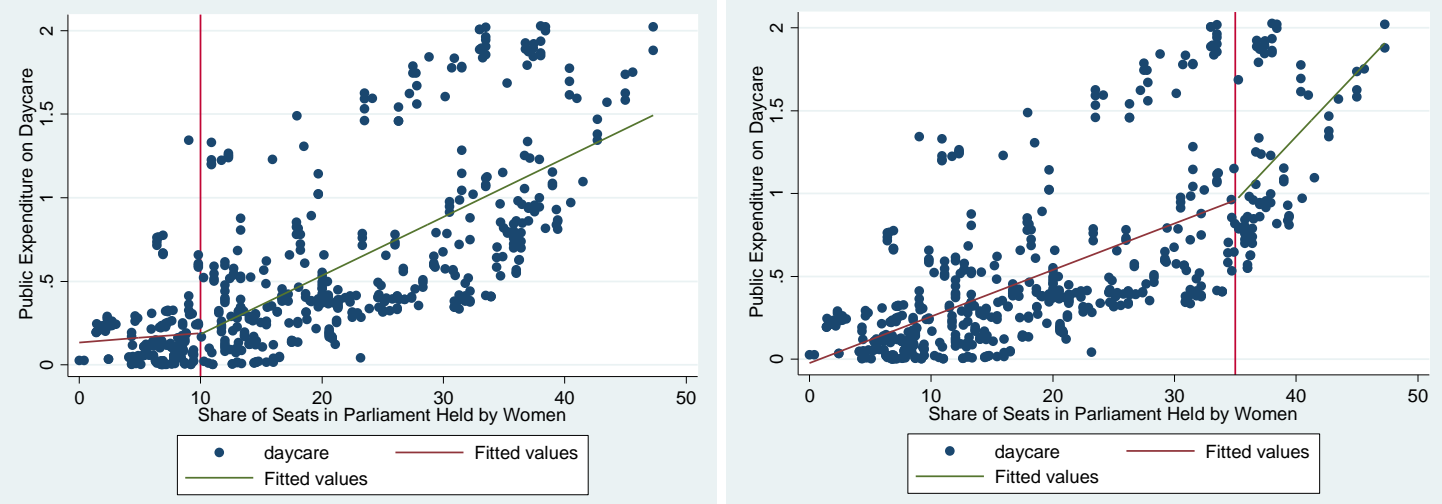

Note: Both variables are shown in percentage. Fitting lines presented above are produced by the breakpoint of 10 (left) and by the one of 35 (right) in the OLS regression models. 


\section{APPENDICES}

\begin{tabular}{lllll} 
Appendix A. Descriptive Statistics for all Study Variables (N = 442) & \\
\hline Variable & Mean & SD & Min & Max \\
\hline Healthcare expenditure & 6.138 & 1.271 & 2.658 & 9.738 \\
Daycare expenditure & .556 & .516 & .003 & 2.027 \\
Education expenditure & 5.299 & 1.175 & 2.029 & 8.740 \\
Women's legislative representation & 19.853 & 11.997 & 0 & 47.3 \\
Female labor force participation rate & 61.884 & 11.621 & 33.395 & 80.915 \\
Trade openness & 73.189 & 38.291 & 15.924 & 278.99 \\
Population aged 65 and older & 14.340 & 2.327 & 8.877 & 21.495 \\
Birth rate & 1.229 & .218 & .817 & 2.176 \\
Population aged under 15 & 19.173 & 3.197 & 13.293 & 30.582 \\
Union density & 39.093 & 20.979 & 7.576 & 87.442 \\
Social pact & .244 & .430 & 0 & 1 \\
Unemployment rate & 7.106 & 3.896 & .457 & 24.171 \\
Real GDP per capita (log) & 10.113 & .340 & 9.018 & 11.036 \\
Seats of Left parties & 39.546 & 40.332 & 0 & 100 \\
Seats of Christian Right parties & 1.337 & 9.668 & 0 & 86.2 \\
\hline
\end{tabular}


Appendix B. Correlation Matrix for All Study Variables $(\mathrm{N}=442)$

\begin{tabular}{|c|c|c|c|c|c|c|c|c|c|c|c|c|c|c|c|}
\hline Variable & 1 & 2 & 3 & 4 & 5 & 6 & 7 & 8 & 9 & 10 & 11 & 12 & 13 & 14 & 15 \\
\hline 1. Healthcare & - & & & & & & & & & & & & & & \\
\hline 2. Daycare & .608 & - & & & & & & & & & & & & & \\
\hline 3. Education & .580 & .694 & - & & & & & & & & & & & & \\
\hline 4. Representation & .537 & .707 & .663 & - & & & & & & & & & & & \\
\hline 5. Fem. labor force & .547 & .599 & .537 & .656 & - & & & & & & & & & & \\
\hline 6. Trade openness & .041 & .102 & .114 & .234 & -.114 & - & & & & & & & & & \\
\hline 7. Aged over 64 & .522 & .394 & .104 & .397 & .321 & -.034 & - & & & & & & & & \\
\hline 8. Birth rate & -.201 & -.077 & .170 & -.183 & -.092 & .076 & -.710 & - & & & & & & & \\
\hline 9. Aged under 15 & -.378 & -.249 & .037 & -.331 & -.296 & .027 & -.816 & .860 & - & & & & & & \\
\hline 10. Union density & .020 & .486 & .449 & .428 & .183 & .245 & -.004 & .172 & .180 & - & & & & & \\
\hline 11. Social pact & -.006 & -.006 & .003 & .038 & -.121 & .087 & .046 & -.014 & -.038 & .001 & - & & & & \\
\hline 12. Unemployment & -.185 & -.182 & -.164 & -.180 & -.486 & -.132 & -.005 & -.059 & .102 & -.076 & .134 & - & & & \\
\hline 13. Real GDP & .599 & .361 & .346 & .462 & .566 & .220 & .384 & -.270 & -.496 & -.136 & -.081 & -.403 & - & & \\
\hline 14. Left parties & .011 & .141 & .080 & .174 & .097 & -.122 & .171 & -.032 & -.084 & .066 & .097 & .097 & -.034 & - & \\
\hline 15. Christian Right & .217 & -.032 & -.073 & .070 & .026 & -.053 & .154 & -.180 & -.163 & -.064 & -.076 & .054 & .034 & -.090 & - \\
\hline
\end{tabular}




\begin{tabular}{|c|c|c|c|c|c|}
\hline & $\begin{array}{l}\text { Healthcare } \\
\text { (990) }\end{array}$ & $\begin{array}{l}\text { Healthcare } \\
\text { (990) }\end{array}$ & $\begin{array}{l}\text { Daycare } \\
\text { (581) }\end{array}$ & $\begin{array}{l}\text { Education } \\
\text { (633) }\end{array}$ & $\begin{array}{l}\text { Education } \\
\text { (633) }\end{array}$ \\
\hline Representation & $\begin{array}{l}.023 * * \\
(.004)\end{array}$ & $\begin{array}{l}.023 * * \\
(.004)\end{array}$ & $\begin{array}{l}.013^{* *} \\
(.002)\end{array}$ & $\begin{array}{l}.038^{* *} \\
(.007)\end{array}$ & $\begin{array}{l}.038^{* *} \\
(.007)\end{array}$ \\
\hline $\begin{array}{l}\text { Female labor } \\
\text { force }\end{array}$ & $\begin{array}{l}.027^{* *} \\
(.003)\end{array}$ & $\begin{array}{l}.027^{* *} \\
(.003)\end{array}$ & $\begin{array}{l}.012 * * \\
(.001)\end{array}$ & $\begin{array}{l}.020^{* *} \\
(.005)\end{array}$ & $\begin{array}{l}.021^{* *} \\
(.005)\end{array}$ \\
\hline Trade openness & $-.001(.001)$ & $-.001(.001)$ & $\begin{array}{l}-.002^{* *} \\
(.000)\end{array}$ & $-.002(.002)$ & $-.002(.002)$ \\
\hline Elderly & $.163 * *(.011)$ & $.159 * *(.011)$ & & & \\
\hline Birth rate & & & $.233(.129)$ & & \\
\hline Youth & & & $\begin{array}{l}-.028 * * \\
(.008)\end{array}$ & $.150 * *(.011)$ & $.148 * *(.011)$ \\
\hline Union density & $.004 *(.002)$ & $.004 *(.002)$ & $\begin{array}{l}.009^{* *} \\
(.000)\end{array}$ & $\begin{array}{l}.017^{* *} \\
(.002)\end{array}$ & $\begin{array}{l}.017^{* *} \\
(.002)\end{array}$ \\
\hline Social pact & $.107(.066)$ & $.111(.066)$ & $.019(.032)$ & $.127(.077)$ & $.118(.076)$ \\
\hline Unemployment & $\begin{array}{l}.057 * * \\
(.009)\end{array}$ & $\begin{array}{l}.056^{* *} \\
(.009)\end{array}$ & $.009(.005)$ & $\begin{array}{l}.034^{* *} \\
(.006)\end{array}$ & $\begin{array}{l}.035^{* *} \\
(.006)\end{array}$ \\
\hline GDP (log) & $.930 * *(.110)$ & $.920 * *(.111)$ & $\begin{array}{l}.182^{* *} \\
(.040)\end{array}$ & $\begin{array}{l}1.233^{* *} \\
(.222)\end{array}$ & $\begin{array}{l}1.188^{* *} \\
(.227)\end{array}$ \\
\hline Left parties & $.001(.001)$ & $.001(.001)$ & $.000(.000)$ & $-.001(.001)$ & $-.001(.001)$ \\
\hline Christian Right & $\begin{array}{l}.012^{* *} \\
(.002)\end{array}$ & $.001(.005)$ & $-.000(.001)$ & $\begin{array}{l}-.006^{* *} \\
(.002)\end{array}$ & $\begin{array}{l}.038^{* *} \\
(.012)\end{array}$ \\
\hline $\begin{array}{l}\text { Constitutional } \\
\text { structure }\end{array}$ & $-.007(.024)$ & $-.010(.024)$ & $\begin{array}{l}-.073^{* *} \\
(.008)\end{array}$ & $.080(.069)$ & $.089(.071)$ \\
\hline $\begin{array}{l}\text { FLR*Christian } \\
\text { Right }\end{array}$ & & $\begin{array}{l}.001^{* *} \\
(.000)\end{array}$ & & & $\begin{array}{l}-.002 * * \\
(.000)\end{array}$ \\
\hline Constant & $\begin{array}{l}-8.302 * * \\
(.990)\end{array}$ & $\begin{array}{l}-8.166^{* *} \\
(.987)\end{array}$ & $\begin{array}{l}-2.134^{* *} \\
(.425)\end{array}$ & $\begin{array}{l}-12.86^{* *} \\
(2.083)\end{array}$ & $\begin{array}{l}-12.47 * * \\
(2.124)\end{array}$ \\
\hline R squared & .614 & .616 & .647 & .523 & .526 \\
\hline
\end{tabular}

Note: Unstandardized regression coefficients are shown with panel-corrected standard errors in parentheses. ${ }^{*} \mathrm{p}<.05 ;{ }^{* *} \mathrm{p}<.01$ 


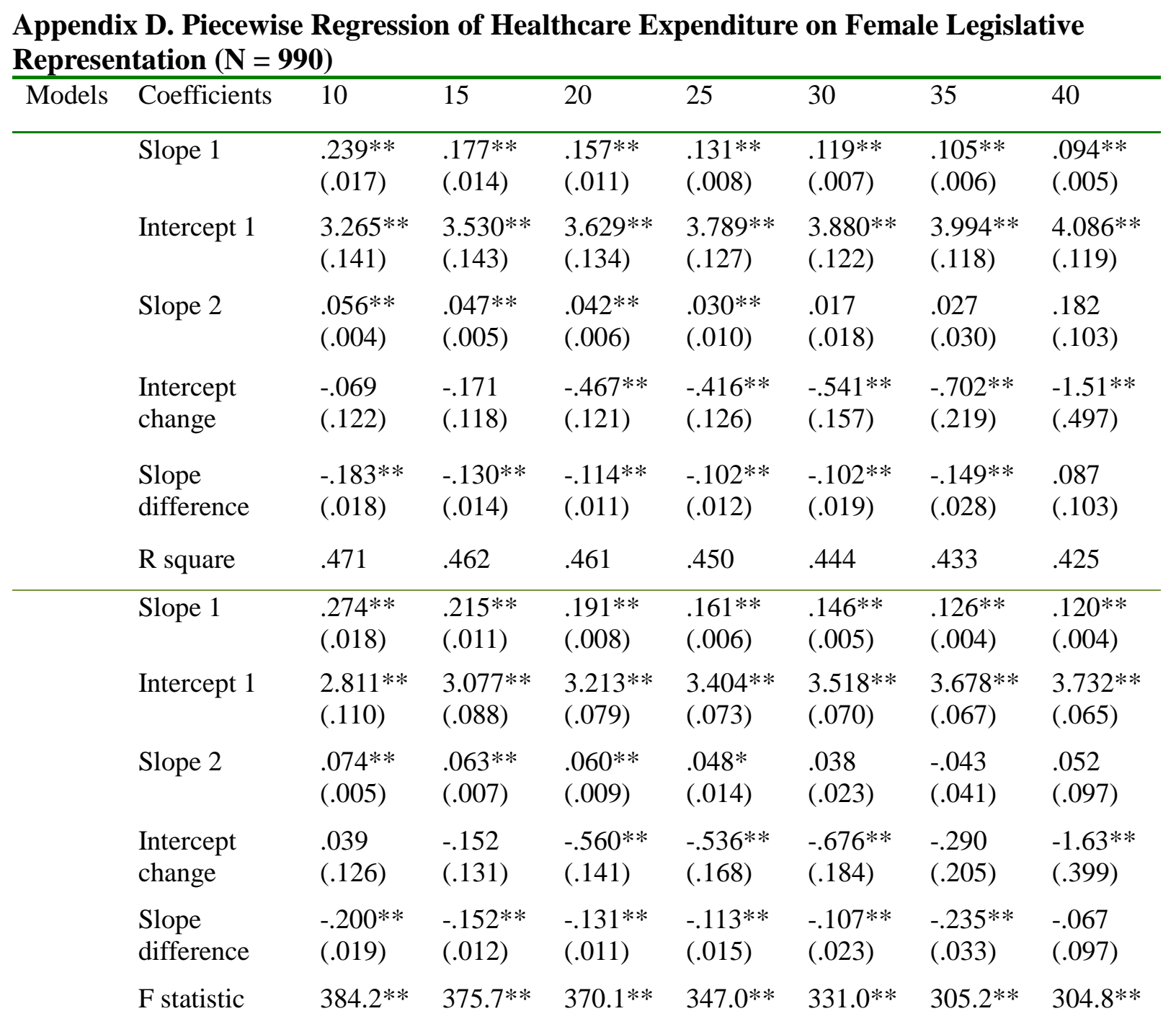

Note: Unstandardized regression coefficients are shown with standard errors in parentheses. ${ }^{*} \mathrm{p}<.05 ;{ }^{* *} \mathrm{p}$ $<.01$ 